Krasinsky Vladislav

Doctor of law, colonel, member of ONMKS of the CEC of Russia

\title{
Legal positions of Russian and foreign constitutional justice bodies about the range limits of state sovereignty
}

Abstract: In the article the author examines the questions of domestic and international rule of law and jurisdictions, substantiates the mechanisms of solving conventional and constitutional collisions. Relying on the practice of German, Austria, Italy, Great Britain and the Russian Federation constitutional courts, the author exposes the problem of international organizations jurisdiction acknowledgement and obligatoriness of respective decisions of supranational organs.

Key words: state sovereignty, ambits of state sovereignty, collisions of domestic and international rule of law, organs of constitutional justice, Constitutional Court of the Russian Federation, European Court of Human Rights, European Convention on Human Rights.

Publication Source: Krasinskiy V.V. The legal position of Russian and foreign bodies of constitutional justice within limits of state sovereignty // electoral legislation and practice. Number 1. 2016. P. 46-54.

For a long time conflict between national and international legal norms and jurisdictions, opportunities and limits of limits of state sovereignty, jurisdiction concessions to foreign legal systems have been causing scientific and practical interest. This perspective has gained relevance for several reasons:

- in connection with the legal authorization in a number of national laws (including Russian) provisions of the "rule" ( "primary") of international legal regulation;

- in connection with the regular attempts by the leading nations of the AngloSaxon legal system to extend its jurisdiction and to exercise the functions of the international law-making and justice;

- in connection with the adoption of the various organs of international justice (mainly the European Court of Human Rights (hereinafter - ECHR) some "conflict" decisions that infringe on basic constitutional principles and foundations of the national legal systems 
Let's consider listed problems of mutual relations between national and international legal systems.

Currently there is no international law that would establish how the contradiction should be resolved between national and international law in the case of split between them. The question is left to the discretion of the legislator and the law enforcement agencies of each ${ }^{1}$ state.

However, as noted by the Russian political scientists, on the wave of ultraliberal ideology of the 90s. the XX century in a range of federal laws Monistic provisions were enshrined, directly or indirectly involve primary (precedence over the Constitution) international legal norms to regulate specific areas of public relations in the Russian ${ }^{2}$ Federation.

This situation has caused experts expect the debate on the need to determine the ratio of international legal and constitutional legal regulation, development of approaches to the grounds and within the limitations of state sovereignty, the development of sound legal mechanisms to resolve conflicts between supranational and national ${ }^{3}$ bodies.

${ }^{1}$ International law / A.A. Kovalev S.V. Chernichenko. M .: Omega - L, 2006. P. 102. The degree of monistic or dualistic countries in terms of the relationship between international and domestic law depends on the approach to the introduction of international standards into national law. Some states (for example the Netherlands, Japan, Austria) give international treaties precedence over their Constitutions. In most countries (France, Spain, Russia, and others) international treaties have a higher status than ordinary legislation, but lower than the Constitution. In other countries (UK, USA) - the status of customary law.

${ }^{2}$ For example, art. 2 of the Labor Code, Part 3 of Article 3 of the Criminal Executive Code, Art. 6 of the Federal Law "On the State Policy of Russian Federation in respect of compatriots abroad", Article 1 of the Federal Law "On the basis of compulsory social insurance", Part 1 of Art. 4 of the Federal Law "On General Principles of Local Government in the Russian Federation." This position was justified by the literal interpretations of the monistic theory of the primacy of international law over domestic. See. Kiselev. The limit compliance // PE-Lawyer. 2013. № 49; I. Puzanov between the Convention and national laws // PE-Lawyer. 2011. № 6.

${ }^{3}$ Avakyan S.A. Russian constitution: nature, evolution and modernity. M., 1997, p. 205206; Budylin S.L. Convention or the Constitution? International law and the limits of state sovereignty // Act. 2013. № 12; Dzhagaryan A.A. The concept of sovereign democracy in the constitutional dimension / Sovereign democracy in the constitutional and legal dimension. Sat. articles and materials. M .: Ros. Gas, 2007, p. 141, 143.; Zorkin V. Limit compliance // Ros. gas. 2010 October 29; Zorkin V.D. Right in the context of global change: a monograph. M .: Norma, 2013. p. 176, 180, 190; Sadraddinov O. European Convention on Human Rights and the national legal systems of the countries - members of the Council of Europe. The role of the Committee of Ministers // Lawyer - international affairs. 2005. № 2; Khudoley K.M. The constitutionality of the 
It was argued that such a regulation is directly contrary to the principles of supremacy and direct effect of the Constitution (Part 2 of Article 4, Part 1 of Art. 15 of the Constitution), and that it undermines state sovereignty. As an additional argument cited legal provisions h. 1 tbsp. 17 of the Russian Constitution, which establishes the requirement of compliance with the recognition and guarantee of the Russian Federation of the rights and freedoms of man and citizen of the Russian Constitution; norms of Art. 79 and p. "G" h. 2 tbsp. 125 of the Constitution, excluding the adoption of international treaties of the Russian Federation, the provisions of which would be at variance with the constitutional ${ }^{4}$ order.

Question of the relationship of national and international law, the possibilities and ambits of state sovereignty is inextricably linked to the willingness of a particular state voluntarily assume an international element in the scope of its jurisdiction and thereby restrict the content of their own national jurisdiction.

Adjudgement of the jurisdiction of international organizations and relevant mandatory standards do not conflict with the goals of achieving internal national interests of a sovereign state based on the balance of constitutionally protected values in its Constitution. International law, as incorporated by the state's will in its national legal system, must not ignore the objectives and principles of the legal system. In this regard, international law must be interpreted and applied at the national level, both in terms of international law, the purposes and principles and in accordance with relevant guidelines of domestic ${ }^{5}$ law.

A common point of view of the "rule" of international law is very superficial and simplistic. It is told about only a priority of the international treaty in applying the law in the event of a collision. As for the Constitution, it has a dominant position in all conflict situations.

ECHR and the enforceability of decisions // Bulletin of Perm State University. Jurisprudence. 2013. Vol. 2.

${ }^{4}$ Ebzeev B.S., Aybazov R.A., Krasnoryadtsev S.L. Globalization and state unity of Russia. M .: Formula rights, 2006. 7 S. 184; Dzhagaryan A.A. The concept of sovereign democracy in the constitutional dimension / Sovereign democracy in the constitutional and legal dimension. Sat. articles and materials. M .: Ros. gas., 2007, p. 142.

${ }^{5}$ Borisov I.B. Electoral sovereignty. M .: ROIIP, 2010. P. 121-122. 
The second group of problems that highlight the issue of conflict of national and international legal norms, possibilities and ambits of state sovereignty during the interaction between national and international legal systems, are regular attempts of the leading states of the Anglo-Saxon legal family which unreasonably expand its jurisdiction and perform the functions of the international law-making and justice .

It should be noted that the US is the only country which not only "helps" national parliaments to adopt domestic legislation, but also it passes laws for other countries. Examples of common jurisdiction of the United States in other countries is the law on religious freedom in countries around the world on January 27, 1998, Democracy Act in Russia in 2002, Democracy Act in Belarus on 20 October 2004 have extraterritorial effect US laws "On foreign corrupt Practices »(foreign corrupt Practices Act) in 1977," On strengthening the fight against terrorism in the United States and beyond "1993, UK law" On bribery »(United Kingdom bribery Act) 2010 Another element of the US "universal" jurisdiction was the "Magnitsky Act" (by Sergei Magnitsky Rule of Law Accountability Act of 2012), which is based on allegations of systematic violations in Russia of fundamental human rights. This law allows the US authorities to evaluate the activities of Russian officials and private individuals, to file charges against Russian citizens, infringe on extrajudicial their property and other legitimate interests on the basis of allegations of violations of national, foreign and international legal norms.

Reflecting on the problem of improving international justice, V.D. Zorkin noted the persistent spread of the sphere of international relations of case AngloSaxon $^{6}$ law. It is told about the use of American and British judicial decisions to prosecute suspects outside the national territory. These norms have tried to legally justify the killing of Osama bin Laden in Pakistan, the application of rules of the

\footnotetext{
${ }^{6}$ It should be noted that the ECHR, which will be discussed below, is also the institution's case-law system. See p. 1 of Article 28 of the Convention for the Protection of Human Rights and Fundamental Freedoms.
} 
Anglo-Saxon "provocation to commit a crime" in the course of his arrest in Thailand and subsequent extradition to the US of a Russian citizen V. ${ }^{7}$ Bout.

The lawyers of the UK and the US are making active efforts to spread these trials "precedents" in the practice of international justice. For this purpose, the decision of the International Criminal Court in relation to the leaders of Malawi, Chad and Libya, which allegedly appear sufficient grounds precedent for similar decisions on any "dictators" of any state. "Precedent" Libya is seen as a legal basis for the forcible removal from power by means of an "international coalition" President of Syria B. Assad.

The author shares the position of VD Zorkin, that "such a transformation of international justice will inevitably lead to its replacement trivial settling of accounts, tyranny, clothed in a form of judicial ${ }^{8}$ verdicts."

The third group of problems that need actualizing understanding the nature of the relationship of national and supra-national bodies, developing new approaches to the grounds and within the limitations of state sovereignty refers to the adoption of the ECHR "conflict" decisions that infringe on basic constitutional principles and foundations of the national legal systems.

Initially, when the ECHR was created it was expected that the Court will consider only the specific complaints of alleged (committed) violations of the requirements of the Protection of Human Rights and Fundamental Freedoms of 1950 (hereinafter - the Convention) (with the right to award the prevailing party "fair compensation" for property damage, non-pecuniary damage and reimbursement of costs and expenses), but over time the change in status occurred and the Court's case practice. In 2004, the European Court of Justice in accordance with the Resolution of the Council of Europe Committee of Ministers on May 12, 2004 began to publish a so-called "pilot-judgment» the need to change national law enforcement and

${ }^{7}$ Zorkin V.D. Right in the context of global change: a monograph. M .: Norma, 2013. P. 415.

${ }^{8}$ Zorkin V.D. Ibid. S. 265. 
judicial practice, to recommend the adoption of other measures entailing legal ${ }^{9}$ consequences. The recommendations on the harmonization of the legal framework and judicial practice would be welcomed if they were, in some cases, not a substitute for the control of the national legislation and did not affect the constitutional foundations of the state and were not forced to be secured in the control mechanism of the execution of the ECHR judgments in accordance with Art. 46 of the Convention.

This evolution of the legal status of the European Court of Justice and the unilateral extension of his personality caused a natural reaction of a number of leading European constitutional courts (primarily Germany, Austria, Italy, Great Britain and Russia).

One of the first steps to develop the constitutional-legal doctrine to protect its sovereignty and form within its limitations began to the Federal Constitutional Court.

In some of its resolutions - on May 29, 1974, on October 11, 1985, on October 14, 2004 and on July 13, 2010 the Federal Constitutional Court of Germany has formulated and substantiated the legal position "of limited legal force of judgments". According to this position, the government is obliged to execute the decision of the ECHR within the participating parties in the proceedings in respect of a particular matter in dispute, the ECHR. However, "the state is entitled to disregard the Court's decision in the cases and parts contradicting constitutional values protected by the Basic Law of ${ }^{10}$ Germany."

In a judgment of 29 May 1974 (known as the Solange-1) The Federal Constitutional Court has declared that it intends to maintain its competence to verify the rules of the EU law and the European Court of Justice decisions in terms of their

${ }^{9}$ The practice of "pilot judgments" ECHR arose in 2004 after the adoption in March 2004 of the Council of Europe Committee of Ministers resolution recommended by the European Court of Justice to fix the systemic problems and prescribe the "general measures", including the adoption and amendment of legislation. Resolution Res (2004) 3 of the Committee of Ministers on judgments revealing12 May 2004 // // URL: Https:wcd. coe. int / ViewDoc. jsp? id = 743257 463.

${ }^{10}$ Zorkin V.D. Right in the context of global change: a monograph. M .: Norma, 2013. P. 
compliance with human rights as set out in the Basic Law of Germany, as long as the European communities would not have its own catalog of human rights, which would be adequate to the catalog of the rights established by the basic ${ }^{11}$ law.

A similar approach is used by the Constitutional Court of the Italian Republic which did not agree with the findings of the ECHR in relation to cross-border pension payments, which were formulated in its Resolution of 31 May 2011 on the case of "Maggio and others against Italy". In particular, in the Resolution of 19 November 2012 in case number 254/2012, it pointed out that compliance with international obligations can not be the cause of reducing the level of protection already laid down in the domestic legal order, but, on the contrary, can and should be an effective tool extension of this ${ }^{12}$ protection.

In a decision dated October 12, 1993 the German Federal Constitutional Court on the constitutionality of the Treaty on European Union (the Maastricht Treaty) to ensure its compliance with Art. 38 of the Basic Law of Germany, which guarantees German citizens with the right to vote, the right to take part in the election of the German $^{13}$ Bundestag. Applicant believes that the Maastricht Treaty reduces the powers and tasks of the Bundestag and restricts its ability to affect the legitimacy and the exercise of power at the state level, which, in turn, violates the principle of democracy. The Federal Constitutional Court of Germany, although it admitted the disputed constitutional treaty, formulated the most important legal positions of the relationship between international obligations and state sovereignty.

In the Maastricht judgment, the Federal Constitutional Court of Germany has left behind him, and not for the ECHR, a right to decide questions of compliance with the rules of the EU competence, which is transmitted at the EU level, and also to declare EU acts ultra vires, i.e. adopted in violation of the authority.

${ }^{11}$ Giants A.S. Wanted pragmatics: Constitutional Court of the Russian and Eurasian rule of law // Comparative constitutional review. 2014. № 5. p. 18.

${ }^{12}$ Paragraph 4 of the Decree of the Constitutional Court on July 14, 2015 № 21-P.

${ }^{13}$ Decision of the Federal Constitutional Court of Germany on 12 October 1993 MaastrichtUrteil des Bundesverfassungsgerichtes vom 12.10.1993 // 
More rigid legal position was formulated by the German Federal Constitutional Court in its judgment of 14 October 2004 on the complaint of Goerguelu. According to the Federal Constitutional Court, the "Basic Law for the Federal Republic of Germany aims to integrate Germany into the legal community of peaceful free states, but does not provide for rejection of sovereignty. Therefore, it does not contradict the purpose of commitment to international law if the legislature, exceptionally, does not comply with the law of treaties, provided that it is the only possible way to avoid the violation of fundamental constitutional principles" ${ }^{14}$.

In addition to this, the Federal Constitutional Court of Germany the ratio of the ECHR status has been determined and the national judicial systems of the States Parties to the Convention. In particular, it was pointed out in the absence of the Convention grounds for establishing the primacy of the ECHR judgments on decisions of national ${ }^{15}$ courts.

However, the Federal Constitutional Court of Germany pointed out that the nature of the legal obligations arising from state authorities in connection with the ECHR case law, is entirely dependent on the scope of their competence and breadth of the authority, which granted the relevant authorities by law. At the same time, national courts, under any circumstances, must take into account any decisions of the ECHR concerning it's previously reviewed cases, and if these courts are entitled to re-examine such cases - to decide, taking into consideration the existing ECHR positions provided the inadmissibility of violation of the substantive law of the State $^{16}$.

Thus, the Federal Constitutional Court of Germany reiterated that the provisions of the Convention and acts of the ECHR are an additional source of

\footnotetext{
${ }^{14}$ Paragraph 30 (Part I C) Order of the Second Senate of 14 October 2 BvR 1481/04 (the official website of the Federal Constitutional Court of Germany http://www.bundesverfassungsgericht.de/en/decisions/rs20041014_2bvr148104en.html)

${ }^{15}$ Section 18 ibid .

${ }^{16}$ Paragraph 30 (part I C) ibid.
} 
interpretation of the contents and scope of fundamental rights fixed by the German Basic Law and subject to domestic control.

In a judgment of 30 June 2009 in the case of Lissabon-Vertrag concerning the constitutionality of the Treaty of Lisbon, the Federal Constitutional Court stated that the EU is competent to consider acts for their conformity with the "constitutional identity 'of the Basic Law of Germany, and not only allows but also obliges the government not to execute the EU acts and to take measures to protect the constitutional identity.

Similar approaches can be found in the constitutional-legal practice of other European states.

In 1987, at the conclusion of the legal limits of the ECHR rulings came the Constitutional Court of Austria. Noting the need to take into consideration the jurisprudence of the ECHR and its solutions, the Austrian Constitutional Court at the same time pointed out that must be guided by the principles of the Constitution and therefore can not prevent the application of the decisions of the European Court and legal positions that are contrary to the constitutional ${ }^{17}$ principles.

The Supreme Court of the Great Britain and Northern Ireland in its decision of 16 October 2013 stressed the unacceptability of the British legal system findings and interpretation of the Convention in the judgment of the European Court of Human Rights on 6 October 2005 in the case "Hirst v. United Kingdom" for the limitation of voting rights of convicted ${ }^{18}$ persons. According to the legal position of the Supreme Court, decisions of ECHR are not perceived as subject to unconditional execution to the United Kingdom, - as a general rule, they are "taken into account"; adherence to these decisions is recognized only possible in the event that they are not contrary to the fundamental substantive and procedural rules of national ${ }^{19}$ law.

${ }^{17}$ Austrian Constitutional Court judgment of 14 October 1987 on the case № B 267/86.

18 The European Court of Human Rights on March 30, 2004 "Hirst v. United Kingdom" Bulletin of the European Court of Human Rights. Russian edition. Number 2006. 4.

${ }^{19}$ In accordance with Art. 2 of the Law of the United Kingdom on Human Rights in 1998, regarding the case of human rights, the British courts must 'be taken into account' the ECHR practice // Human Rights Act 1998. Art 2. 
With regard to Russia the issue of conflicts of constitutional interpretation of the Constitutional Court of the national provisions and the interpretation of the Convention by the European Court of Justice, under which the impugned norm is recognized as incompatible with the Convention, first arose in October 2010 after the European Court of Human Rights judgment in the case "Konstantin Markin v Russia $^{20 "}$.

As B.R. Tuzmukhamedov noted, "the first time the European Court in the strict legal form questioned the decision of the Constitutional ${ }^{21}$ Court. "In this definition from January 15, 2009 № 187-of-the Constitutional Court notes that the legal regulation, which provides military-women to have a paid leave to take care of a child until the age of three and which does not recognize such a right for the military-men (they can take advantage of a short vacation), does not violate the provisions of the Constitution on equality of rights and freedoms, regardless of ${ }^{22}$ gender.

However, the ECHR determined that the entitlement to leave to care for the child soldiers, the women, while refusing that right to men soldiers, "devoid of reasonable justification." In connection with this unprecedented is the conclusion of the ECHR that "viewed by the Russian legislation is not compatible with the Convention and finds widespread in the legal mechanism of the problem relating to a significant number of ${ }^{23}$ people."

${ }^{20}$ On the Rights of the European Court's judgment of man from October 7, 2010 in the case of "Konstantin Markin v Russia» (Konstantin Markin v Russia.)7 October 2010; Grand Chamber judgment of 22 March 2012 // Bulletin of the European Court of Human Rights. Russian edition. 2012. № 6.

${ }^{21}$ http://www.ng.ru/politics/2010-10-13/3_kartblansh.html

${ }^{22}$ Determination of the Constitutional Court on January 15, $2009 \mathrm{~N} 187-\mathrm{O}-\mathrm{O}$ "On the refusal to accept for consideration the complaint of citizen Konstantin Markin a violation of his constitutional rights in articles 13 and 15 of the Federal law "on state benefits for citizens with children", articles 10 and 11 of the Federal law "on status of servicemen", article 32 of the Regulations on the procedure of military service and paragraphs 35 and 44 of the Regulation on appointment and payment of state benefits to citizens" The text has not been published officially.

${ }^{23}$ On the Rights of the European Court's judgment of man from October 7, 2010 in the case of "Konstantin Markin v Russia» (Konstantin Markin v Russia.)7 October 2010; Grand Chamber judgment of 22 March 2012 // Bulletin of the European Court of Human Rights. Russian edition. 2012. № 6 . 
The basis of the constitutional-legal doctrine of protection of state sovereignty of the Russian Federation was founded by the Russian Federation Constitutional Court on February 26, 2010 № 4-P and on December 6, 2013 № 27-P, in which the following legal positions have been ${ }^{24}$ formulated:

- In the process of production on the revision of an enforceable court decision the court of general jurisdiction can come to a conclusion about the impossibility of the execution of ECHR judgments without abandoning the application of the provisions of the Russian Federation, previously recognized by the Russian Constitutional Court as they do not violate the constitutional rights of the applicant in his particular case. In such a case before a court of law raises the question of the constitutionality of the above legal provisions, which caused the violation of the Convention in their interpretation of the ECHR.

- Identification of unconstitutional statutes and their exclusion from the number of existing legal provisions can only be the cumulative result of cooperation between courts of different kinds of jurisdiction based on the delineation of their competence, involving, on the one hand, the implementation of a court of law the powers to raise the question of the constitutionality of the relevant standards before the Russian Constitutional Court and on the other - the duty of the Constitutional Court finally resolve this issue.

- In order to eliminate conflicts of domestic and supranational rules of court of general jurisdiction suspends and appeals to the Constitutional Court of the Russian Federation on the verification of compliance with the Russian Constitution applied in norms that violate the provisions of the Convention.

In other words, the Constitutional Court of the Russian Federation ordered the courts in case of conflict between the legal positions of the ECHR and the

${ }^{24}$ Decision of the Constitutional Court on February 26, 2010 № 4-P "On the case on the constitutionality of Part 2 of Art. 392 Code of Civil Procedure of the Russian Federation in connection with complaints A.A.Doroshka citizens A.E.Kota and E.Y. Fedotova "; Resolution of the Constitutional Court on December 6, 2013 № 27-P "On the case on the constitutionality of the provisions of Article 11, paragraphs 3 and 4 of Part 4 of Article 392 of Code of Civil Procedure of the Russian Federation in connection with the request of the Presidium of the Leningrad District Military Court" // Ros. gas. 2013. December 18. 
Constitutional Court with respect to the contested provision to apply to the Constitutional Court of the Russian Federation.

In June 2014 provided for in the Resolution of the Constitutional Court of the Russian Federation dated December 6, 2013 № 27-P mechanism for resolving conflicts of domestic and conventional rules was enshrined in the Federal Constitutional Law "On Amendments to the Federal Constitutional Law" on Constitutional Court of Russian Federation"25. Article 101 of the Act was supplemented with a provision that the court in a retrial in connection with the adoption of interstate body for the protection of human rights and freedoms solutions, which states the violation of the Russian Federation's human rights and liberties in the application of the law or certain of its provisions; it concluded that the possibility of the application of the relevant law can be resolved only after the confirmation of its conformity to the Constitution of the Russian Federation, must make a request to the Constitutional Court of the Russian Federation to review the constitutionality of the law.

Selection and implementation of measures by which the ECHR decisions are executed, fall within the discretion of the national legal system (jurisdiction of legislative, judicial and executive bodies). Council of Europe Committee of Ministers only controls the execution of ECHR judgments. It has repeatedly emphasized itself, the Court (ECHR judgment of 13 July 2000 on the case "Scozzari and Giunta against Italy," from 30 June 2005 in the case of "Jahn and others v. Germany" , on 29 March 2006 in the case of "Scordino against Italy," from July 3, 2008 in the case of "Musayev v. Russia", on 3 July 2008 in the case of "Ruslan Umarov against Russia» and others. Therefore, the formulation of the specific requirements for the legislator with the list of necessary legal acts is an invasion of the sovereign powers of the national legislative bodies, which are not foreseen by the Convention.

${ }^{25}$ The federal constitutional law from June 4, 2014 № 9-FKZ "On Amendments to the Federal Constitutional Law" On Constitutional Court of Russian Federation "// Ros. gas. 2014 June 6 . 
The need for a mechanism to overcome the Convention, the constitutional conflicts prompted the Constitutional Court in a judgment of July 14, 2015 № 21-P to formulate a number of conditions under which a State may refuse to execute the decision of the international court:

1. the ECHR interprets the Convention in a different than usual, meaning or performs an interpretation contrary to the object and purpose of the Convention.

2. Consent to be bound to the state of the international treaty has been expressed by him in breach of a provision of its internal law regarding competence to conclude treaties if the violation was manifest.

3. Interpretation of provisions of international treaties on which the decision is based, violates the provisions of domestic law special importance (the Constitution).

4. Unconditional fulfillment of interstate body of decisions taken in disagreement with the interpretation of the Constitution, may result in a violation of its provisions, which are obvious to any subject of international law.

In addition to the judicial mechanism for resolving conflicts of conventionconstitutional (Constitutional Court of the Russian Federation Decree of December 6, 2013 № 27-P), based on the Court's request to review the constitutionality of the impugned rules in a particular case in case of a conflict between the legal positions of the ECHR and the Constitutional court judgment of July 14, 2015 № 21-P has been proposed a non-judicial mechanism to provide interpretation of the Constitution at the request of the President or the Russian Federation. In a situation where the Constitutional Court concludes that the incompatibility of the ECHR decisions with the Constitution, it is not enforceable.

In this case, the Constitutional Court uses the "right of objection" in rare cases and is ready to search for "legitimate compromise", but the definition of the degree of their readiness, he reserves.

Moreover, in the practice of domestic constitutional justice from the outset established approach according to which the generally recognized principles and norms of international law are used as a supranational reference, in accordance with 
which the Russian Federation carried out the rights and freedoms of man and citizen guaranteed by the Constitution. Based on this, the Constitutional Court has resorted to international legal argument for further justification of their legal position, and to clarify the meaning of constitutional provisions, as well as revealing the constitutional legal meaning of certain ${ }^{26}$ laws.

As S.D. Knyazev believes, "logical result of this process is to strengthen cooperation between Russian and international law, actively supported by the Constitutional Court and obtain a sequence of confirmation in its many ${ }^{27}$ solutions."

Currently, the EU member states in order to harmonize the legal framework of the European and national legal systems voluntarily take into account decisions of the ECHR complaints against other states, to change its legislation. However, this reception state to go until the ECHR in its judgment does not affect the sensitive issues and does not violate the limits of state sovereignty.

Constitutional justice is on the path of rapprochement with the European Union on the basis of goodwill and common values. But international humanitarian consensus, providing a common understanding of the rights and freedoms of individuals and the obligations of States to protect them, does not entail rejection of state sovereignty. The criteria for the legitimacy of any public authority, as well as the extent of activity of the courts of the Russian Federation and the assessment of the audited acts provided for by the Constitution, of a higher legal force is no exception. Sovereign power presupposes the sovereign responsibility in the field of human ${ }^{28}$ rights.

At the present stage of harmonization of international and national legal systems, the convergence of lawmaking, law enforcement and judicial practice require an updated concept of state sovereignty, which provides the issues of national jurisdiction of States, jurisdictional issues of supranational bodies and

${ }^{26}$ Zorkin V.D. The modern world, law and the Constitution. M., 2010. P. 485.

${ }^{27}$ Knyazev, S.D. The Constitutional Court in the legal system of the Russian Federation // Journal of Russian law. 2013. № 12.

${ }^{28}$ Ebzeev B.S. Identity and state in Russia: mutual responsibility and constitutional duties. M .: Norma, 2011. P. 28. 
international organizations, as well as the exhaustive list of grounds for international intervention. Developing such a concept is only possible with the involvement of all interested states.

Implementation of the proposed harmonized approach to defining the personality of the State, the jurisdiction of supranational bodies and international organizations, outside the limits of state sovereignty, the development of comprehensive justification for international intervention in the internal affairs of States will avoid "double standards" in international relations and optimize the existing mechanisms for resolving conflicts between supranational and national authorities.

\section{LIST OF SOURCES AND LITERATURE:}

1. International law / ed. A.A. Kovalev S.V. Chernichenko. M .: Omega - L, 2006.

2. Dzhagaryan A.A. The concept of sovereign democracy in the constitutional dimension / Sovereign democracy in the constitutional and legal dimension. Sat. articles and materials. M .: Ros. gas., 2007.

3. Resolution of the Plenum of the Supreme Court on June 27, 2013 № 21 "On application by the courts of general jurisdiction of the Convention for the Protection of Human Rights and Fundamental Freedoms of 4 November 1950 and the Protocols thereto" // Ros. gas. 2013. 5 July.

4. Avakyan S.A. Russian constitution: nature, evolution and modernity. M .: Ros. jurid. ed. House, 1997.

5. Zorkin V. Limit compliance // Ros. gas. 2010 on 29 October.

6. Zorkin V.D. Right in the context of global change: a monograph. M .: Norma, 2013. The

7. Giants A.S. Wanted pragmatics: Constitutional Court of the Russian and Eurasian rule of law // Comparative constitutional review. 2014. 5.number

8. Kniazev S.D. The Constitutional Court in the legal system of the Russian Federation // Journal of Russian law. 2013. № 12.

9. The Constitutional Court judgment of December 6, 2013 № 27-P "On the case on the constitutionality of the provisions of Article 11, paragraphs 3 and 4 of Part 4 of Article 392 of Code of Civil Procedure of the Russian Federation in connection with the request of the Presidium of the Leningrad District Military Court" // Ros. gas. 2013. December 18.

10. Resolution of the Constitutional Court on July 14, 2015 № 21-P "On the case on the constitutionality of provisions of Article 1 of the Federal Law" On ratification of the Convention 
for the Protection of Human Rights and Fundamental Freedoms and its Protocols", paragraphs 1 and 2 of Article 32 of the Federal law "On international treaties of the Russian Federation", parts 1 and 4 of article 11, paragraph 4 of part 4 of article 392 of the Civil Procedure Code of the Russian Federation, parts 1 and 4 of article 13, paragraph 4 of part 3 of article 311 of the Arbitration Procedure Code of the Russian Federation and parts 1 and 4 of Article 15, paragraph 4 of Part 1 of Article 350 of the Code of Administrative Procedure of the Russian Federation and of paragraph 2 of Part 4 of Article 413 of the Russian Federation Code of Criminal Procedure in connection with the request of the State Duma deputies group "// Ros. gas. 2015. July 27.

11. The European Court of Human Rights on March 30, 2004 "Hirst against the United Kingdom» Bulletin of the European Court of Human Rights. Russian edition. 2006. № 4.

12. European Court of Human Rights judgment of 7 October 2010 in the case of "Konstantin Markin v. Russia» 7 October 2010; Grand Chamber judgment of 22 March 2012 // Bulletin of the European Court of Human Rights. Russian edition. 2012. № 6.

13. European Court of Human Rights judgment of 4 July 2013 in the case of "Anchugov and Gladkov v. Russia» Court Bulletin human Rights. Russian edition. 2014. № 2.

14. Decision of the Federal Constitutional Court of Germany on 12 October 1993 Maastricht-Urteil des Bundesverfassungsgerichtes vom 12.10.1993 ///Maastricht_Urteil_1993.pdf

15. Ebzeev B.S. Identity and state in Russia: mutual responsibility and constitutional duties. M .: Norma, 2011. P. 28. 